\title{
PENGARUH PENAMBAHAN NPK DALAM PENDEGRADASIAN LIMBAH CAIR KELAPA SAWIT MENGGUNAKAN ANAEROBIC BAFFLED REACTOR
}

\section{THE EFFECT OF NPK ADDITION IN DEGRADATION OF PALM OIL LIQUID WASTE USING ANAEROBIC BAFFLED REACTOR}

\author{
Panca Nugrahini ${ }^{1}$, Rendy Parningotan $P^{2}$ \\ Fakultas Teknik JurusanTeknik Kimia Universitas Lampung \\ E-mail: pasrendyp@gmail.com
}

Dikirim 4 Agustus 2020, Direvisi 12 September 2020, Disetujui 24 November 2020

\begin{abstract}
Abstrak: Proses pengolahan limbah cair minyak kelapa sawit menggunakan Anaerobic Baffled Reactor memiliki kekurangan dimana effluent pengolaham tersebut tidak seimbang dengan nutrient ataupun substrat yang tersedia di dalam limbah maupun lumpur aktif. Untuk penanganan masalah tersebut maka perlu dilakukan penambahan senyawa nitogen dan fosfor dalam bentuk NPK di dalam activator. Dilakukan 3 variasi perlakuan untuk NPK yaitu sebanyak 2,5 gr; 5 gr dan tanpa NPK. Nilai akhir COD tanpa NPK $2.198 \mathrm{mg} / \mathrm{L} ; 2,5$ gr NPK $843 \mathrm{mg} / \mathrm{L}$; dan 5 gr NPK $731 \mathrm{mg} / \mathrm{L}$. Nilai akhir TSS tanpa NPK 4,9 mg/L; 2,5 gr NPK 5,3 mg/L; dan 5 gr NPK 4,1 mg/L. Nilai akhir VSS tanpa NPK 4,76 mg/L; 2,5 gr NPK 6,186 mg/L; dan 5 gr NPK 6,15 mg/L. Dari hasil analisa dapat disimpulkan bahwa pendegradasian terbaik diperoleh pada penambahan 5 gram NPK.
\end{abstract}

Kata kunci: limbah cair kelapa sawit, anaerobic baffled reactor, NPK

\begin{abstract}
The processing of Liquid Palm Oil Waste using a Anaerobic baffled reactor has disadvantages where the effluent of wastewater treatment are not balanced with nutrients or substrates available in both waste and activated sludge. For handling these problems, it is necessary to add nitrogen and phosphorus compounds in the form of NPK in activators. There are 3 variations of treatment for NPK, which are 2.5, 5 grams and without NPK. The final value of COD without NPK is $2.198 \mathrm{mg} / \mathrm{L}, 2.5 \mathrm{~g}$ of NPK $843 \mathrm{mg} / \mathrm{L}$, and $5 \mathrm{~g}$ of NPK of $731 \mathrm{mg} / \mathrm{L}$. The final value of TSS without NPK is $4,9 \mathrm{mg} / \mathrm{L}, 2.5 \mathrm{~g}$ of NPK which is $5.3 \mathrm{mg} / \mathrm{L}, 5 \mathrm{~g}$ of $\mathrm{NPK} 4.1 \mathrm{mg} / \mathrm{L}$. The final value of VSS without NPK is $4.76 \mathrm{mg} / \mathrm{L}, 2.5 \mathrm{~g}$ of NPK is $6.18 \mathrm{mg} / \mathrm{L}$, and $5 \mathrm{~g}$ of NPK which is $6.15 \mathrm{mg} / \mathrm{L}$. From the results of the analysis it can be concluded that the best degradation is obtained by adding $5 \mathrm{~g}$ of NPK
\end{abstract}

Keywords: liquid palm oil l waste, anaerobic baffled reacto, NPK Media

\section{PENDAHULUAN}

Provinsi Lampung adalah salah satu provinsi memiliki banyak industri pengolahan kelapa sawit di Indonesia. Di provinsi ini tersebar beberapa industri pengolahan kelapa sawit dengan kapasitas pengolahan bervariasi.

Salah satunya yaitu PT. Perkebunan Nusantara VII (Persero) Unit Usaha Bekrie, industri ini banyak mengeluarkan sisa bahan cair organik. Kandungan organik dari industri tersebut memiliki tingkat Chemical Oxygen Demand (COD) yang tinggi yaitu sebesar $55.000 \mathrm{mg} / \mathrm{L}$. Sisa bahan cair tersebut menyebabkan pencemaran yang diakibatkan oleh pembuangan limbah cair ke luar pabrik melalui badan air. Penanganan yang khusus sangat diperlukan sebelum limbah cair tersebut dibuang ke lingkungan (Tobing et al., 2000).

Salah satu perusahaan pengolahan limbah cair yaitu PT. Tunas Baru Lampung (PT. TBL) di kecamatan Terbanggi Besar, kabupaten Lampung Tengah, Provinsi Lampung. Kedua industri tersebut menggunakan beberapa kolam, yang terdiri dari kolam pengutipan minyak (fat pit), kolam pengendapan pasir dan kotoran, kolam pendinginan (cooling pond), kolam anaerob, dan kolam aerob. Kolam yang digunakan pada sistem ini sebanyak 18 kolam. Pengolahan dengan cara tersebut kurang efisien dikarenakan 
membutuhkan kolam yang banyak dan juga besar sehingga dibutuhkan lahan yang luas, hasilnya berupa gas yang berpotensi menimbulkan pemanasan global dan meningkatkan polusi. Limbah dari kolam anaerobik kemudian dilanjutkan ke dalam kolam-kolam aerobik dengan luas minimal kolam aerobik sebesar $20 \mathrm{~m}$ x $40 \mathrm{~m}$. Limbah dalam kolam-kolam anaerobik (anaerob ponds) memiliki waktu tinggal sampai 60 hari. Alasan menggunakan kolamkolam tersebut karena luasnya areal perkebunan, misalnya minimum 5.000 Ha, sehingga bukan menjadi masalah yang berarti dengan kebutuhan lahan yang luas untuk pengelolaan dan pengolahan limbah cair suatu PKS. Akan tetapi ada masalah yang timbul yaitu pada pengoperasian proses pengolahan limbah cair dan perawatan unit-unit prosesnya yang ternyata tidak dijalankan dengan benar, sehingga menyebabkan hasil pengolahannya menjadi tidak optimal. Untuk menangani permasalahan tersebut peneliti mengganti proses tersebut dengan anerobic baffled reactor.

Aplikasi anerobic baffled reactor itu sendiri sudah banyak dilakukan khususnya dalam pengolahan limbah cair, seperti limbah cair tahu, limbah cair potongan hewan, serta air buangan industry (Tobing et al., 2000).

Dari hasil analisa laboratorium untuk ketiga parameter (BOD, COD dan TSS) dapat dilihat korelasinya dengan perubahan waktu tinggal, yaitu bahwa hasil pengolahan limbah cair PKS dengan menggunakan system anerobic baffled reactor menunjukkan efisiensi pengurangan terbaik untuk ketiga parameter tersebut diperoleh pada waktu tinggal 6 hari. Menurut Young (1991) dan Rittmann dan McCarty (2001), selain pengolahan pada industri di atas biofiltrasi juga bisa diterapkan dalam pengolahan limbah cair domestik, bahanbahan kimia, soft drink, bahan makanan, landfill leachate, dan industri farmasi (Rittmann \& McCarty, 2001).

$\begin{array}{ccr}\text { Pada } & \text { proses } & \text { anaerobik } \\ \text { menghasilkan } & \text { sedikit } & \text { lumpur, } \\ \text { menyebabkan } & \text { kebutuhan } & \text { senyawa }\end{array}$ nitrogen dan fosfor untuk pertumbuhan biomassa sedikit, akan tetapi pada kebanyakan limbah cair industri, jumlah kebutuhan nutrient belum mencukupi. Limbah cair yang sudah diproses belum memenuhi baku mutu limbah cair yang dapat dibuang ke lingkungan. Penyebabnya dikarenakan mikroorganisme yang digunakan dalam pengolahan tersebut tidak sesuai dengan banyaknya COD yang terkandung didalam limbah cair, sehingga membutuhkan waktu yang relatif lama dalam pendegradasiannya dan tidak tercapainya tingkat penurunan COD yang diharapkan. Untuk mengatasi permasalahan diatas, maka dibutuhkan penambahan NPK yang bertujuan memberikan nutrisi yaitu berupa senyawa nitrogen dan fosfor dalam bentuk NPK ke dalam aktivator sehingga mikroorganisme dapat lebih maksimal dalam mendegradasikan limbah cair dan mempersingkat waktu tinggal (HRT) limbah cair di dalam reaktor. Proses ini merupakan pengolahan aerobik yang mengoksidasi senyawa organik menjadi $\mathrm{CO} 2, \mathrm{H} 2 \mathrm{O}, \mathrm{NH} 4$ dan sel bio massa baru.

\section{Landasan Teori}

\section{Industri Kelapa Sawit}

Kelapa sawit (Elaeis) adalah tumbuhan industri penting penghasil minyak masak, minyak industri, maupun bahan bakar (biodiesel). Kelapa sawit yang juga memiliki berbagai macam kegunaan baik untuk industri pangan maupun non pangan, oleochemical serta produk samping yang dapat dimanfaatkan antara lain minyak sawit/CPO dan minyak inti sawit antara lain emulsifier, margarin, minyak goring, minyak makan merah, shortening, susu kental manis, vanaspati, confectioneries, es krim, dan yoghurt (Yan Fauzi, 2008). 
Permintaan atas minyak nabati dan penyediaan biofuel telah mendorong peningkatan permintaan minyak nabati yang bersumber dari crude palm oil (CPO) yang berasal dari kelapa sawit. Peningkatan aktivitas industri ini berdampak semakin banyaknya kegiatan yang menghasilkan limbah. Potensi pencemaran limbah cair industri sangat bervariasi tergantung dari macam proses yang dilakukan, kapasitas produk, jenis bahan baku, bahan pewarna, dan bahan penolong yang digunakan serta kondisi lingkungan tempat pembuangannya (Yan Fauzi, 2008).

Parameter yang digunakan untuk menunjukkan karakter limbah cair industri pengolahan kelapa sawit disamakan dengan karakter air buangan industri lainnya yang meliputi parameter fisika dan parameter kimia.

Parameter fisika adalah karakteristik nilai-nilai yang kelihatan secara langsung perubahan yang terjadi, seperti padatan total (padatan tersuspensi, padatan koloidal, padatan terlarut), warna, bau, dan suhu. Sedangkan parameter kimia digunakan untuk mengukur derajat pecemaran air buangan, seperti BOD, COD, $\mathrm{pH}$, senyawa organik, senyawa anorganik, karbohidrat, protein, lemak, dan minyak (Yan Fauzi, 2008).

\section{Jenis Limbah Industri Kelapa Sawit}

Limbah industri kelapa sawit adalah limbah yang dihasilkan pada saat proses pengolahan kelapa sawit. Limbah jenis ini digolongkan dalam tiga jenis yaitu limbah padat, limbah cair, dan limbah gas.

\section{a. Limbah Padat}

Limbah padat yang dihasilkan oleh pabrik pengolah kelapa sawit ialah tandan kosong, serat dan tempurung. Limbah padat tandan kosong banyak yang menghailkan buah tidak lepas di antara celah - celah ulir dibagian dalam. Hal ini terjadi apabila perebusan dan bantingan yang tidak sempurna sehingga pelepasan buah sangat sulit. Serat yang merupakan hasil pemisahan dari fibre cyclone mempunyai kandungan cangkang, minyak dan inti. Kandungan tersebut tergantung dari pemisahan pada fibre cyclone dan proses ekstraksi di screw press. Tempurung yang dihasilkan dari kernel plant yaitu shell separator masih mengandung biji bulat dan inti sawit (Ponten M. Naibaho, 1996).

\section{b. Limbah Gas}

Selain limbah padat dan cair, industri pengolahan kelapa sawit juga menghasilkan limbah bahan gas. Limbah gas ini antara lain gas cerobong dan uap air buangan pabrik kelapa sawit (Yan Fauzi, 2008).

\section{c. Limbah Cair}

Limbah cair juga dihasilkan pada proses pengolahan kelapa sawit. Limbah ini berasal dari hidrosiklon, stasiun klarifikasi dan dari kondensat. Limbah kelapa sawit memiliki kadar bahan organik yang tinggi. Diperlukan degradasi bahan organik yang lebih besar yang disebabkan tingginya kadar limbah cair yang dapat menimbulkan beban pencemaran yang besar (Yan Fauzi, 2008).

\section{Proses Anaerobik \& Mikrobiologi Anaerobik}

Proses anaerobik telah lama digunakan untuk mengolah limbah industri dan limbah kota atau limbah rumah tangga (Amatya, 1996). Proses ini mengubah material organik menjadi gas metana, ammonia dan $\mathrm{H}_{2} \mathrm{~S}$ serta dihasilkan energi panas. Kemajuan teknologi di bidang mikrobiologi saat ini sangat mendukung penyediaan mikroorganisme yang sesuai untuk proses anaerobik di dalam pengolahan limbah industri (McCarty dan Smith, 1986).

Mikrobiologi anaerobik merupakan sistem yang unik dengan beragam kelompok katalis yang mengkonversi senyawa organik kompleks menjadi metan dan $\mathrm{CO}_{2}$. Mikroorganisme anaerobik tidak menggunkan oksigen sebagai akseptor elektron, tetapi pada proses fermentasi donor elektron biasanya berupa senyawa- 
senyawa organik (organik compounds) (Amatya, 1996).

Secara umum bentuk bakteri metanogenik adalah berbentuk batang (bacillus) seperti methanobacterium dan methanobacillus dan berbentuk bulat (coccus) seperti methanococcus dan methanosarcina (Amatya, 1996; Metcalf dan Eddy, 1991).

\section{Perbedaan Pengolahan Aerob \& Anaerob}

Perbedaan utama dari pengolahan secara anaerob dan aerob terletak pada kondisi lingkungannya. Pada pengolahan secara aerob, kehadiran oksigen mutlak diperlukan untuk metabolisme bakteri, sementara pada kondisi anaerob sebaliknya. Berikut ini adalah beberapa perbedaan utama antara pengolahan secara aerob dan anaerob menurut Eckenfelder, et.al (1988):

\section{a. Temperatur}

Temperatur mempengaruhi proses aerob maupun anaerob. Pada proses anaerob, diperlukan temperatur yang lebih tinggi untuk mencapai laju reaksi yang diperlukan. Pada proses anaerob, penambahan temperatur dapat dilakukan dengan dengan memanfaatkan panas dari gas methane yang merupakan by-product proses anaerob itu sendiri.

\section{b. $p H$ dan Alkalinitas}

Proses aerob bekerja paling efektif pada kisaran $\mathrm{pH}$ 6,5-8,5. Pada reaktor aerob yang dikenal dengan istilah completely mixed activated sludge (CMAS), terjadi proses netralisasi asam dan basa sehingga biasanya tidak diperlukan tambahan bahan kimia selama BOD kurang dari $25 \mathrm{mg} / \mathrm{L}$.

Sementara itu proses anaerob yang memanfaatkan bakteri methanogen lebih sensitif pada $\mathrm{pH}$ dan bekerja optimum pada kisaran $\mathrm{pH}$ 6,5-7,5. Sekurang-kurangnya, $\mathrm{pH}$ harus dijaga oada nilai 6,2 dan jika konsentrasi sulfat cukup tinggi maka kisaran $\mathrm{pH}$ sebaiknya berada pada $\mathrm{pH}$ 7-8 untuk menghindari keracunan $\mathrm{H}_{2} \mathrm{~S}$. Alkalinitas bikarbonat sebaiknya tersedia pada kisaran 2500-5000 $\mathrm{mg} / \mathrm{L}$ untuk mengatasi peningkatan asam-asam volatil dengan menjaga penurunan $\mathrm{pH}$ sekecil mungkin. Biasanya dilakukan penambahan bikarbonat ke dalam reaktor untuk mengontrol $\mathrm{pH}$ dan alkalinitas.

\section{c. Produksi Lumpur}

Bagi kebanyakan air limbah, produksi lumpur yang dihasilkan dari pengolahan aerob adalah sebesar $0,5 \mathrm{~kg}$ VSS/kg COD tersisihkan. Sementara itu, pada pengolahan anaerob, produksi lumpur adalah sebanyak $0,1 \mathrm{~kg} \mathrm{VSS} / \mathrm{kg}$ COD tersisihkan. Pada pengolahan aerob, konsentrasi nitrogen yang perlu ditambahkan adalah 8-12 \% dan fosfor sebesar 1,5-2,5\%. Sebagai "rule of thumb", kebutuhan nutrien pada pengolahan anaerob adalah seperlima dari proses aerob.

\section{Bioreaktor Anarobic Baffled Reactor}

Salah satu reaktor hasil modifikasi septic tank dengan penambahan sekat-sekat adalah Anaerobic Baffled Reactor (ABR) atau biasa dikenal dengan Anaerobic Baffled Septic Tank (ABST). Teknologi ini telah digunakan dan dikembangkan oleh Bachman dkk (1985) untuk mengolah limbah cair sintetik dengan kategori kuat (COD $8000 \mathrm{mg} / \mathrm{l}$ ) sampai sedang.

Menurut Manariotis et al.,2002; Wanasen,2003, sistem ABR ini sangat efisien untuk mengolah air buangan sintetis yang relatif kurang kuat (low-strength synthetic wastewater), air buangan dari rumah penjagalan hewan (Polprasert et al., 1992; Wanasen,2003), dan air buangan domestik atau perkotaan (Tosonis et.al, 1994; Orozco et al.,1997; Wanasen, 2003). Selain itu, ABR juga cocok untuk mengolah air buangan yang memiliki kandungan zat tersuspensi tidak terendapkan yang tinggi dan rasio BOD/COD yang rendah, seperti limbah dari kegiatan industri (Wanasen, 2003). Bioreaktor anaerob yang memiliki kompartemen - kompartemen yang dibatasi oleh sekat-sekat vertikal merupakan ciri 
dari reaktor ABR. ABR mampu mengolah berbagai macam jenis influen. Umumnya sebuah ABR terdiri dari kompartemen kompartemen yang tersusun seri (Wanasen, 2003).

Rangkaian kompartemen pada ABR secara seri memiliki keuntungan dalam membantu mengolah substansi yang sulit didegradasi (Sasse, 1998). Aliran limbah cair diarahkan menuju ke bagian bawah sekat oleh susunan seri sekat tergantung maupun tegak dan juga tekanan dari influen sehingga air limbah dapat mengalir dari inlet menuju outlet (Wanasen, 2003).

Bagian bawah sekat tergantung dibengkokkan $45^{\circ}$ untuk mengarahkan aliran air dan mengurangi channelling atau aliran pendek. Bagian downflow lebih sempit dibanding upflow untuk mencegah akumulasi mikroorganisme. Dalam aliran ke atas, aliran melewati sludge blanket, sehingga limbah dapat kontak dengan mikroorganisme aktif. Arah aliran limbah dalam sebuah reaktor ABR dapat dilihat pada gambar berikut :

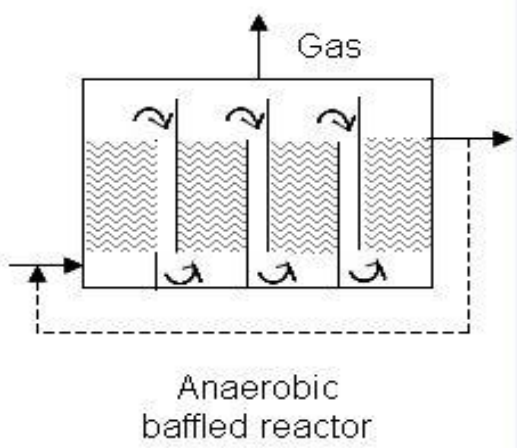

Gambar 1. Anaerobic Baffled Reactor

Akibat karakteristik aliran dalam reaktor ABR dan gas yang dihasilkan dari tiap-tiap kompartemen tersebut, mikroorganisme di dalam reaktor akan naik secara perlahan dan kemudian membentuk lapisan (selimut) lumpur yang melayang, tetapi bergerak secara horizontal turun ke bagian bawah reaktor dengan laju yang relatif lambat sehingga meningkatkan waktu tinggal sel (Cell Retention Time) atau
CRT lebih dari 100 hari pada waktu detensi hidraulik (HRT) 20 jam (Grobicki amd Stuckey, 1991).

Hal ini juga akan memisahkan waktu retensi hidrolik (HRT) dengan waktu detensi solid (SRT). Oleh karena itu, konsentrasi mikroorganisme yang tinggi dan penyisihan COD yang baik dapat tercapai. Waktu retensi hidrolik yang singkat cukup bagus untuk pengolahan limbah cair berkekuatan rendah. HRT yang terlalu lama akan dapat menyebabkan kelaparan mikroorganisme pada kompartemen terakhir (Orozco, 1988).

Sebuah unit ABR dengan 3 ruang reaktor, yang telah dimodifikasi, menyediakan sludge retention time (SRT) yang lebih lama dan kinerja yang lebih baik daripada reaktor yang memiliki 2 ruang reaktor. Analisis selanjutnya mengatakan bahwa selain menghilangkan solid, 3 ruang reaktor juga lebih efisien dalam mengkonversikan solid yang terperangkap ke dalam bentuk metan (Barber and Stuckey, 1999).

ABR memiliki banyak variasi kompartemen (2-11 kompartemen). Umumnya ABR memiliki 4 kompartemen yang dirangkai secara seri. Kompartemen terakhir dapat ditambahkan filter di bagian atas unit, dengan maksud untuk menyisihkan partikel padatan yang masih ada. Sebuah settler dapat diletakkan di akhir unit instalasi, untuk mengendapkan partikel-partikel padatan yang masih ada (Sasse, 1998).

Salah satu penelitian di Durban Institute of Technology Afrika Selatan menyatakan bahwa sekat-sekat pada ABR mengatur jalannya aliran dan menahan sejumlah lumpur (biomassa) berkonsentrasi tinggi pada kompartemen - kompartemen yang dibentuk oleh sekat-sekat tersebut. Aliran air yang melewati kompartemen tersebut secara bertahap menyebabkan meningkatnya konsentrasi biomassa. Melalui beberapa prosedur yang dipakai seperti Scanning Elektron Microscopy 
(SEM), Fluorescent Insitu Hybridisation (FISH) dan DNA sequencing diketahui bahwa biomassa tersebut dapat beradaptasi secara optimal dengan kondisi reaksi yang spesifik dalam kompartemen. Komunitas biomassa ini juga menunjukkan kekebalan terhadap zat-zat bersifat toksik dan juga tahan dari organic shock loading. Selain itu dengan melakukan kulturisasi patogen, penelitian diatas juga memberikan hasil deaktivasi indikator patogen pada komunitas biomassa ABR. Secara umum, penambahan sekat-sekat pada ABR akan meningkatkan efisiensi pengolahan karena dapat memperpanjang waktu detensi (waktu kontak antara air limbah dengan konsentrasi massa bakteri).

\section{B. Kelebihan dan Kekurangan ABR}

Menurut Grobicki dan Stuckey (1989), bioreaktor yang efisien harus memiliki waktu tinggal biomassa yang lama dan terjadi pencampuran yang merata untuk menjamin terjadinya kontak yang baik antara sel dan substratnya. ABR dapat memenuhi faktor ini. Mikroorganisme di dalam reaktor cenderung terangkat dan terendapkan kembali akibat terbentuknya gas selama proses. Mikroorganisme tersebut akan bergerak secara perlahan ke arah horizontal dan dengan demikian, air limbah akan bersentuhan dengan biomassa aktif berjumlah besar dalam waktu tinggal yang cukup pada saat melewati reaktor.

Mikroorganisme yang tumbuh di setiap kompartemen berbeda-beda tergantung kondisi lingkungan yang mempengaruhi dan materi yang didegradasi sehingga materi organik dalam setiap kompartemen juga bervariasi. Populasi yang bermacammacam ini meningkatkan ketahanan ABR terhadap berbagai variasi beban influen, temperatur serta $\mathrm{pH}$ (Bell, 1997).

Keuntungan yang paling signifikan dari sebuah reaktor ABR adalah

kemampuannya untuk memisahkan antara proses asidogenesis dan metanogenesis secara longitudinal di bagian bawah reaktor, sehingga memungkinkan tersedianya kondisi pertumbuhan yang sesuai untuk masing-masing kelompok mikroorganisme yang berbeda (Polprasert et al., 1992).

Selain itu konstruksi reaktor ABR ini murah dan sederhana, tidak ada bagian

yang bergerak atau pencampuran secara mekanik sehingga kehilangan bakteri

didalam reaktor sangat kecil dan aliran keluar relatif bebas dari padatan biomassa. Yang mempengaruhi kontak antara mikroorganisme dengan substrat sehingga mengkontrol performansi reaktor dan transfer masa adalah tingkat pencampuran dan hidrodinamika yang terjadi dalam reaktor (Polprasert et al., 1992).

Sebuah ABR mudah untuk dibangun dan tidak mahal karena tidak ada

bagian yang bergerak atau mesin pencampur (mechanical mixing devic. Desain ABR dapat memisahkan asidogenesis dan metanogenesis sehingga keuntungan yang didapat signifikan. Reaktor berlaku seperti sistem dua fase tanpa ada kontrol masalah dan biaya yang tinggi. Selain itu karena HRT dan SRT terpisah maka volume limbah yang akan diolah lebih besar dibandingkan reaktor tercampur seperti CSTR dimana HRT $=$ SRT. Karena mikroorganisme tidak tercampur merata dalam reaktor maka konsentrasi mikroorganisme yang terbawa keluar di efluen relatif sedikit (Polprasert et al., 1992).

Boopathy et.al (1988), disadur dari Madyanova, 2005, menemukan bahwa ABR menunjukkan kestabilan kinerjanya. Selain itu, pengurangan 
resiko clogging dan ekspansi sludge bed akibat adanya kehilangan mikroorganisme juga cukup stabil. Hasil observasi menyatakan efisiensi penyisihan COD mencapai sampai dengan $90 \%$, dan kecepatan produksi metan mencapai 4 volume/day/unit volume dari reaktor.

Menurut Sasse, 1998, kinerja ABR dalam penyisihan COD adalah sekitar

$65-90 \%$ sedangkan untuk penyisihan BOD adalah sekitar 70-95 \%. Proses maturasi harus diperhatikan pada 3 bulan pertama. Lumpur harus dibersihkan dalam jangka waktu yang teratur, hampir sama halnya dengan pembersihan lumpur pada tangki septik. Tetapi lumpur tetap harus ada yang ditinggalkan dalam reaktor, supaya efisiensi unit instalasi terus meningkat. Dan perlu diperhatikan, bahwa jumlah lumpur pada kompartemen dibagian awal unit ABR lebih banyak daripada di kompartemen akhir.

C. Aktivator

Pengolahan limbah cair pada umumnya dilakukan dengan menggunakan metode biologi. Metode ini merupakan metode yang paling efektif dibandingkan dengan metode kimia dan fisika. Proses pengolahan limbah dengan metode biologi adalah metode yang memanfaatkan mikroorganisme sebagai katalis untuk menguraikan material yang terkadung di dalam air limbah. Mikroorganisme yang dijadikan sebagai biokatalis dapat berasal dari lumpur aktif atau substrat lain yang memiliki kandungan mikroorganisme anaerobik seperti feses sapi segar.

\section{a. Lumpur Aktif}

Lumpur aktif (activated sludge) adalah proses pertumbuhan mikroba tersuspensi. Proses ini pada dasarnya merupakan pengolahan aerobik yang mengoksidasi material organik menjadi
$\mathrm{CO}_{2}$ dan $\mathrm{H}_{2} \mathrm{O}, \mathrm{NH}_{4}$ dan sel biomassa baru. Proses ini menggunakan udara yang disalurkan melalui pompa blower atau melalui aerasi mekanik. Sel mikroba membentuk flok akan mengendap di tangki penjernihan. Kemampuan bakteri dalam membentuk flok menentukan keberhasilan pengolahan limbah secara biologi karena akan mempermudah pemisahan partikel dan air limbah. Lumpur aktif dicirikan oleh beberapa parameter antara lain (Lettinga, G., van Velsen, A.F.M., et.al. 1980):

\section{Mixed-Liqour Suspended Solids (MLSS)}

Isi tangki aerasi dalam sistem lumpur aktif disebut sebagai mixed-liqour yang diterjemahkan sebagai lumpur campuran. MLSS adalah jumlah total dari padatan tersuspensi yang berupa material organik dan mineral, termasuk didalamnya adalah mikroorganisme. MLSS ditemukan dengan cara menyaring lumpur campuran dengan kertas saring, kemudian filter dikeringkan pada temperatur $105^{\circ} \mathrm{C}$, lalu berat padatan dalam contoh ditimbang.

\section{Mixed-Liqour Volatile Suspended Solids (MLVSS)}

Material organik pada MLSS diwakili oleh MLVSS yang berisi material organik non mikroba, serta mikroba hidup dan mikroba mati, dan hancuran sel (Davis M.L. dan Cornwell, D.A., 1991). MLVSS diukur dengan cara memanaskan sampel filter yang telah kering pada keadaan temperatur $600^{\circ} \mathrm{C}-650^{\circ} \mathrm{C}$, dan mempunyai nilai yang mendekati $65-75 \%$ dari MLSS.

\section{Hydraulic Retention Time (HRT)}

Waktu tinggal hidraulik (HRT) adalah waktu rata-rata yang dibutuhkan oleh larutan influent masuk dalam tangki aerasi untuk proses lumpur aktif; nilainya berbanding terbalik dengan laju pengenceran (D).

$$
\mathrm{HRT}=\frac{1}{D}=\frac{V}{Q}
$$


Keterangan : V = Volume tangki aerasi

$\mathrm{Q}=$ Laju influent air limbah ke dalam tangki aerasi

$\mathrm{D}=$ Laju pengenceran

\section{Umur Lumpur (Sludge age )}

Umur lumpur adalah waktu tinggal rata-rata mikroorganisme dalam sistem. Jika HRT memerlukan waktu dalam jam, maka waktu tinggal sel mikroba dalam tangki aerasi dapat dalam hari lamanya. Parameter ini berbanding terbalik dengan laju pertumbuhan mikroba. Umur lumpur dihitung dengan formula sebagai berikut :

$\frac{\underset{M L S S \times V}{\text { Umur Lumpur }}}{S_{e} \times Q_{e}+S S_{w} \times Q_{w}}$ (hari) $=$

Keterangan : MLSS $=$ MixedLiqour Suspended Solids (mg/l)

$$
\mathrm{V}=\text { Padatan tangki aerasi }
$$
(L)

$\mathrm{SS}_{\mathrm{c}} \quad=\quad$ Padatan tersuspensi dalam effluent $(\mathrm{mg} / \mathrm{l})$

$\mathrm{SS}_{\mathrm{w}}=$ Padatan tersuspensi dalam lumpur limbah (mg/l)

$$
\begin{gathered}
\mathrm{Q}_{\mathrm{c}}=\text { Laju effluent limbah } \\
\left(\mathrm{m}^{3} / \mathrm{hari}\right) \\
\begin{array}{c}
\mathrm{Q}_{\mathrm{w}}=\text { Laju influent limbah } \\
\left(\mathrm{m}^{3} / \mathrm{hari}\right)
\end{array}
\end{gathered}
$$

Lumpur hanya dapat bertahan antara 515 hari dalam konvensional lumpur aktif. Pada musim dingin lumpur dapat bertahan lebih lama dibandingkan musim panas. Parameter penting untuk mengendalikan operasi lumpur adalah laju pemuatan organik, supply oksigen, dan pengendalian dan operasi tangki pengendapan akhir. Tangki ini mempunyai dua fungsi ; penjernihan dan penggemukan mikroba. Untuk operasi rutin, kita harus mengukur laju pengendapan lumpur dengan menentukan indeks volume lumpur (SVI).

\section{b. Feses Sapi}

Pada umumnya mikroorganisme anaerobik banyak ditemukan dalam perut hewan memamah biak seperti sapi. Mikroorganisme yang ada di dalam rumen tersebut akan ikut keluar bersamaan dengan feses dari hewan tersebut (Behrendt, J., 2000).

Mikroorganisme yang ada di dalam feses sapi dapat dijadikan sebagai substrat tambahan ke dalam aktivator karena jumlah mikroorganisme anaerob yang jumlahnya banyak. Meskipun memiliki mikroorganisme aerob susbtrat ini tetap akan dapat melakukan pendegradasian secara anaerob karena secara alami mikroorganisme aerob akan mati apabila proses dibuat tanpa udara (Behrendt, J., 2000).

Feses sapi memiliki keseimbangan nutrisi, mudah diencerkan dan relative dapat diproses secara fermentasi. Selain itu, feses yang masih segar lebih mudah diproses dibandingkan dengan feses yang lama atau telah mengering (Behrendt, J., 2000).

\section{c. Nutrisi}

Mikroorganisme akan menggunakan bahan-bahan organik yang terkandung dalam limbah cair sebagai makanannya, tetapi ada beberapa unsur kimia penting yang banyak digunakan sebagai nutrisi untuk pertumbuhan bakteri sehingga pertumbuhan bakteri optimal. Sumber nutrisi tersebut antara lain :

Makro nutrient Sumber makro nutrient yang sering ditambahkan antara lain adalah $\mathrm{N}, \mathrm{S}, \mathrm{P}, \mathrm{K}, \mathrm{Mg}, \mathrm{Ca}, \mathrm{Fe}, \mathrm{Na}$, dan $\mathrm{Cl}$. Unsur nitrogen dan phospor yang digunakan biasanya diperoleh dari urea dan TSP dengan perbandingan 5:1 (Metcalf \& Eddy, 2004).

Mikro nutrient Sumber mikro nutrient yang penting antara lain adalah $\mathrm{Zn}, \mathrm{Mn}, \mathrm{Mo}$, $\mathrm{Se}, \mathrm{Co}, \mathrm{Cu}$, dan $\mathrm{Ni}$. Penggunaan mikronutrient adalah 1-100 $\mu \mathrm{g} / \mathrm{L}$ (Robert $\mathrm{H}$. Perry, 1997). Karena jika terlalu banyak justru merupakan racun bagi 
mikroorganisme.

Penambahan

mikronutrient $\mathrm{Cu}$ lebih dari $1 \mathrm{mg} / \mathrm{L}$ mengakibatkan efisiensi penurunan TOC menjadi menurun (Y.P. Ting, *H. Imai and S. Kinoshita, 1994).

\section{Penelitiam Terdahulu}

Pengaruh Penambahan Feses Sapi Pada Lumpur Aktif Dalam Pendegradasian Limbah Cair Pabrik Kelapa Sawit Menggunakan Reaktor Upflow Anaerobic Sludge Blanket (UASB)

Penelitian ini bertujuan untuk mencari komposisi limbah cair kelapa sawit dengan aktivatornya untuk mendegradasi kandungan organik limbah cair kelapa sawit seperti COB, BOD, TSS secara anaerobic selama 36 hari menggunakan Reaktor Upflow Anaerobic Sludge Blanket (UASB). Activator yang digunakan yaitu campuran feses sapi segar dan lumpur aktif dengan perbandingan 60\%:40\%. Campuran antara limbah cair kelapa sawit dengan aktivatornya yang digunakan antara lain yaitu 60\%:40\%, 80\%:20\%, dan 100\%:0\%. Pendegradasian kandungan COD tertinggi dicapai pada campuran 80\%:20\% sebesar $4.162 \mathrm{mg} / \mathrm{l}$. Pendegradasian TSS tertinggi dicapai pada campuran 100\%:0\% sebesar $1.215 \mathrm{mg} / \mathrm{l}$. (Ardy, 2013).

Diharapkan dengan perubahan alat yang digunakan menjadi anaerobic baffled reactor, dan mengambil salah satu campuran aktivator yang terbaik dapat meningkatkan proses pendegradasian pada limbah cair kelapa sawit.

Karakterisasi Perombakan Anaerobik Campuran Limbah Cair Industri Menggunakan Reaktor UASB (Upflow Anaerobic Sludge Blanket) Dengan Variasi COD Yang Tinggi Pada Kondisi Optimum

Penelitian ini bertujuan untuk mempelajari fenomena proses pengolahan campuran limbah cair industri dengan proses anaerobik menggunakan reaktor UASB dengan bantuan lumpur aktif anaerobik. Hal yang akan diamati pada penelitian ini yaitu pengaruh peningkatan COD umpan dengan waktu tinggal yang lebih cepat pada kondisi optimum $(\mathrm{pH}$ dan nutrisi alami) terhadap efisiensi pengolahan limbah cair campuran.

COD umpan diatur pada 5.000, 10.000, dan $20.000 \mathrm{mg} / \mathrm{L}$, dengan HRT diatur pada 12, 10, 8, dan 6 jam. Efisiensi reduksi COD limbah cair campuran yang dihasilkan cukup baik, hingga mencapai rentang 63,20\%-82,90\%. Akumulasi gas rata-rata yang dihasilkan tiap eksperimen besar, mencapai renyang $155-350 \mathrm{~mL} / \mathrm{hari} . \mathrm{pH}$ alami influent asam tidak terlalu mempengaruhi proses degradasi dan effluent dari reactor ini mempunyai $\mathrm{pH}$ yang mendekati netral dengn rentan $\mathrm{pH}$ 5,01-6,94 (McCart, P.L., 1964).

Diharapkan dengan perubahan reaktor menjadi anaerobic baffled reactor dan dengan penambahan aktivator berupa substrat yang memiliki mikroorganisme yang aktif seperti feses sapi segar akan mengubah efisiensi perombakan kandungan organik dari limbah cair yang akan didegradasi sehingga lebih cepat dan lebih besar tingkat pendegradasiaannya.

Pengaruh Variasi Waktu Tinggal Terhadap Kadar BOD dan COD Limbah Tapioka dengan Metode Rotating Biological Contactor

Penelitian ini bertujuan untuk mencari komposisi limbah cair tapioka terbaik dengan menggunakan Rotating Biological Contactor. Hal yang akan diamati pada penelitian ini yaitu penurunan kadar COD, BOD, TSS, dan meningkatkan nilai $\mathrm{pH}$ pada limbah cair tepung tapioka dengan variasi waktu tinggal antara 12, 24, 32 dan 48 jam dengan kecepatan putaran sebesar $100 \mathrm{rpm}$.

Berdasarkan hasil penelitian yang telah dilakukan dengan waktu tinggal 48 jam, reaktor Rotating Biological Contactor terbukti dapat menurunkan kandungan COD sebesar $97.9 \%$, BOD turun sebesar $96.1 \%$, TSS turun sebesar $89.63 \%$ dan 
peningkatan nilai $\mathrm{pH}$ sebesar

47.4\% dan kondisi limbah belum diolah, dalam penelitian ini waktu tinggal 48 jam mempengaruhi nilai konsentrasi BOD dan COD dengan jumlah penurunan yang memenuhi baku mutu, dimana dengan waktu tinggal yang lebih lama maka kontak limbah dengan bakteri biofilm akan semakin lama sehingga memberikan efisiensi penurunan konsentrasi BOD dan COD.

Diharapkan dengan perubahan reaktor menjadi anaerobic baffled reactor dan dengan penambahan aktivator berupa substrat yang memiliki mikroorganisme yang aktif seperti feses sapi segar akan mengubah efisiensi perombakan kandungan organik dari limbah cair yang akan didegradasi sehingga lebih cepat dan lebih besar tingkat pendegradasiaannya.

\section{METODOLOGI}

Alat-alat yang digunakan pada penelitian ini adalah Anarobic Baffled Reactor, pH-meter, neraca elektronik, oven, spektrofotometer Vis, dan COD reactor, furnace, dan porcelain. Prosedur kerja pada penelitian ini meliputi preparasi, pengukuran COD menggunakan spektrofotometer Vis, serta pengukuran TSS, dan VSS.

Pada tahap preparasi, limbah cair kelapa sawit Seeding anaerobic biofilter reactor dilakukan dengan menginokulasi lumpur inokulum sebesar $40 \%$ dari kerja reaktor. Selanjutnya umpan ditambahkan dengan feses sapi sebanyak $20 \%$ dari lumpur inokulum. Setelah itu, umpan yang telah ditambahkan dengan feses sapi dialirkan secara batch recycle untuk beberapa hari sampai kondisi stabil yaitu reduksi COD mencapai $80 \%$. Metode yang digunakan untuk pengukuran COD adalah COD reactor digestion method (USEPA).

\section{HASIL DAN PEMBAHASAN}

Hasil percobaan terhadap limbah cair industri pengolahan kelapa sawit
PTPN VII Unit Bekrie yang dinyatakan dalam hasil pengukuran kualitas COD, TSS sebelum keluar reaktor fixed-bed di dalam seluruh sistem dapat dilihat pada Tabel 1.

Tabel 1. Data kondisi awal limbah cair

\begin{tabular}{cc}
\hline Parameter & Limbah Cair Industri Sawit \\
\hline $\operatorname{COD}(\mathrm{mg} / \mathrm{L})$ & 52.000 \\
$\mathrm{TSS}(\mathrm{mg} / \mathrm{L})$ & 2.213 \\
$\mathrm{pH}$ & 4,6 \\
\hline
\end{tabular}

(Sumber: Anonim, 2018)

Pada saat percobaan dimulai limbah cair kelapa sawit segar yang berada di bak sedimentasi pertama mempunyai kandungan COD 52.000 $\mathrm{mg} / \mathrm{L}$, terjadi perubahan kandungan menjadi $50.789 \mathrm{mg} / \mathrm{L}$ untuk percobaan tanpa NPK, $49.827 \mathrm{mg} / \mathrm{L}$ dengan penambahan 2,5 g NPK dan $49.827 \mathrm{mg} / \mathrm{L}$ dengan penambahan $5 \mathrm{~g}$ NPK dimana kualitas limbah cair segar tersebut diperkirakan karena adanya proses pengolahan biologis selama perjalanan pengangkutan dari lokasi PKS ke laboratorium yang membutuhkan waktu tempuh selama 4 jam. Limbah cair segar yang baru diambil langsung dari pabrik tersebut dikemas dalam jerigen plastik yang bervolume 20 liter dan dalam kondisi tertutup rapat, dikarenakan proses pengolahan biologis yang terjadi berlangsung secara anaerobik sehingga menghasilkan gas metan yang terbentuk dan tertahan didalam jerigen yang tertutup rapat sehingga terjadi penggelembungan jerigen-jerigen limbah cair PKS. Adanya pengolahan biologis itu, menyebabkan terjadinya degradasi bahan-bahan pencemar yang terkandung dalam limbah cair tersebut. Dengan demikian, kandungan bahan pencemar baik COD telah berkurang. 
Limbah tersebut dimasukkan kedalam reaktor melalui bagian samping. Proses start-up dilakukan selama 15 hari, dikarenakan pada hari ke 15 kandungan COD limbah cair kelapa sawit sudah terdegradasi mencapai $80 \%$, start-up dimulai tanggal 9 Maret 2018 pada pukul 09.00 WIB sampai dengan 24 Maret 2018 pukul 09.00 WIB. Menurut Peraturan Menteri Lingkungan Hidup Republik Indonesia No. 5 tahun 2004 tentang Baku Mutu Air Limbah, kualitas limbah cair yang telah layak dibuang ke sistem perairan seperti dalam Tabel 2.

Table 2. Baku mutu air limbah industri minyak sawit

\begin{tabular}{lc}
\hline Parameter & $\begin{array}{c}\text { Limbah Cair Industri } \\
\text { Sawit }\end{array}$ \\
\hline COD (mg/L) & 350 \\
TSS (mg/L) & 250 \\
$\mathrm{pH}$ & $6,0-9,0$ \\
Minyak \& Lemak & 25 \\
(mg/L) &
\end{tabular}

(Sumber : Kementrian Negara Lingkungan Hidup.2004)

Pertama analisa kadar COD limbah cair kelapa sawit tanpa NPK yaitu 50.780 $\mathrm{mg} / \mathrm{L}$ setelah 33 hari turun menjadi 2.198 $\mathrm{mg} / \mathrm{L}$, penurunan kadar COD sebesar $48.542 \mathrm{mg} / \mathrm{L}$. Untuk 2,5 g NPK, kadar COD limbah cair kelapa sawit pada hari pertama yaitu $49.827 \mathrm{mg} / \mathrm{L}$ turun menjadi $843 \mathrm{mg} / \mathrm{L}$ pada hari ke 33, penurunan kadar COD sebesar $48.984 \mathrm{mg} / \mathrm{L}$. Untuk 5 g NPK kadar COD limbah cair kelapa sawit dengan pada hari pertama yaitu $49.827 \mathrm{mg} / \mathrm{L}$ turun menjadi $731 \mathrm{mg} / \mathrm{L}$ pada hari ke 33, penurunan kadar COD sebesar $49.096 \mathrm{mg} / \mathrm{L}$.

Dari Gambar 1 dapat disimpulkan bahwa penurunan kadar COD paling besar terjadi pada NPK sebanyak $5 \mathrm{~g}$, diikuti penambahan NPK 2,5 $\mathrm{g}$ kemudian tanpa NPK. Dari hasil analisa laboratorium untuk ketiga reaktor dapat dilihat korelasinya, yaitu bahwa hasil pengolahan limbah cair pabrik kelapa sawit dengan menggunakan sistem anerobic baffled reactor menunjukkan pengurangan terbesar untuk ketiga parameter tersebut diperoleh pada penambahan $5 \mathrm{~g}$ NPK, karena banyak mikroorganisme yang hidup, sehingga banyak juga enzim-enzim yang dihasilkan untuk mereaksikan zat-zat kimia. Mikroorganisme mampu menghasilan banyak enzim, dikarenakan faktor lingkungan serta nutrisi yang diberikan pada $5 \mathrm{~g}$ NPK. Pada penambahan $5 \mathrm{~g}$ NPK, $\mathrm{pH}$ lingkungan,netral yaitu 6,6-7, mikroorganisme berupa bakteri seperti hidrolitik, asidogen, asetogen serta metanogen hidup pada kondisi lingkungan $\mathrm{pH}$ netral. Lingkungan dengan $\mathrm{pH}$ yang sesuai sangat menguntungkan karena mikroorganisme mampu hidup dan sangat reaktif, sehingga mikroorganisme mampu berkembang biak dan menghasilkan banyak mikroorganisme yang bisa menghasilkan enzim. Nutrisi juga dibutuhkan oleh mikroorganisme, penambahan $5 \mathrm{~g}$ NPK mampu memenuhi kebutuhan nutrisi mikroorganisme, bahkan sebagai sumber energi. Sumber energi digunakan untuk aktivitas metabolisme yaitu semua reaksi kimia yang terjadi di dalam organsime tersebut.

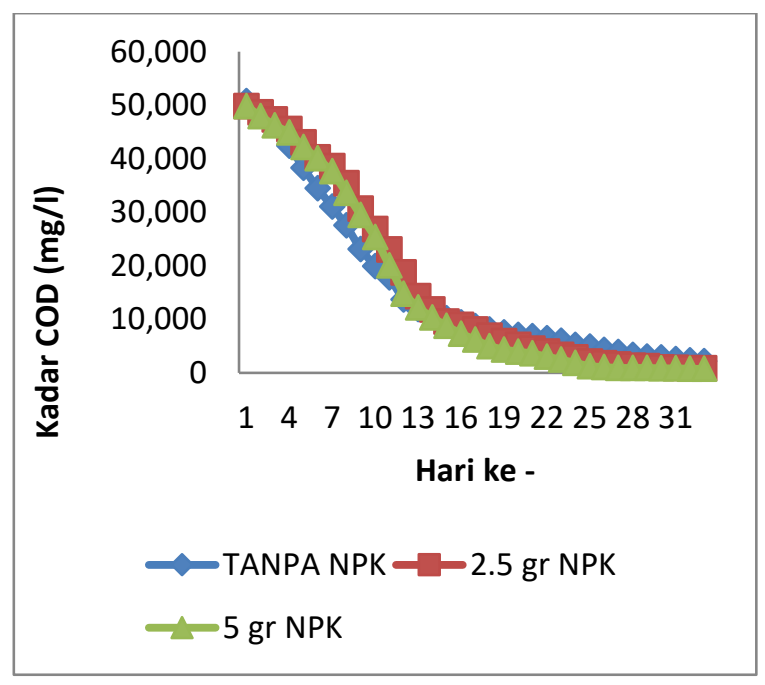


Gambar 2. Profil penurunan kadar COD

limbah cair kelapa sawit

Pada penambahan 2,5 g NPK, mikroorganisme hidup, akan tetapi hanya sedikit yang aktif sehingga hanyak sedikit enzim yang dihasilkan. Hal tersebut disebabkan karena NPK yang diberikan masih belum cukup sehingga kebutuhan konsentrasi nitrogen, fosfor dan kalium dalam fasa cair berturutturut masih belum tercukupi. (Ritmann \& McCarty, 2001).

Pada hari pertama analisa kadar TSS limbah cair kelapa sawit tanpa NPK yaitu $3.420 \mathrm{mg} / \mathrm{L}$ setelah 33 hari turun menjadi $490 \mathrm{mg} / \mathrm{L}$, penurunan kadar TSS sebesar $2.930 \mathrm{mg} / \mathrm{L}$. Untuk penambahan 2,5 g NPK, kadar TSS limbah cair kelapa sawit pada hari pertama yaitu $3.280 \mathrm{mg} / \mathrm{L}$ turun menjadi $530 \mathrm{mg} / \mathrm{L}$ pada hari ke 33, penurunan kadar TSS sebesar $2.750 \mathrm{mg} / \mathrm{L}$. Untuk penambahan $5 \mathrm{~g} \mathrm{NPK}$, kadar TSS limbah cair kelapa sawit dengan pada hari pertama yaitu 3.020 $\mathrm{mg} / \mathrm{L}$ turun menjadi $416 \mathrm{mg} / \mathrm{L}$ pada hari ke 33, penurunan kadar TSS sebesar $2.610 \mathrm{mg} / \mathrm{L}$. Hasil lengkat seperti tersaji dalam Gambar 3.

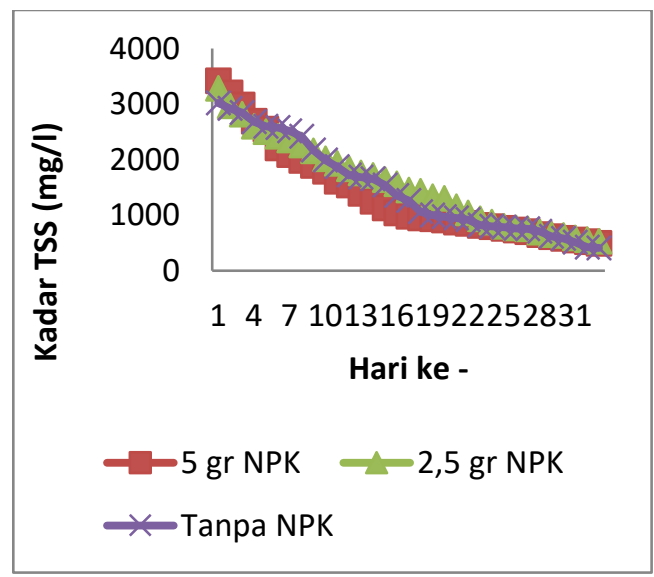

Gambar 3. Profil penurunan TSS (Total Suspended Solid) limbah cair kelapa sawit

Dari Gambar 3 dapat diketahui bahwa efisiensi pengurangan terbesar untuk ketiga parameter tersebut diperoleh pada penambahan $5 \mathrm{~g}$ NPK. Akan tetapi secara keseluruhan limbah kelapa sawit mengalami penurunan kadar TSS. Penurunan nilai TSS yang semakin kecil menunjukkan juga semakin kecil proses degradasi bahan organik tersebut. Penurunan Total Suspended Solid (TSS) disebabkan juga karena proses degradasi oleh mikroorganisme pada limbah cair kelapa sawit yang mengandung bahan organik berupa protein, lemak, dan karbohidrat rantai panjang. Terlihat semakin menurun kadar Total Suspended Solid. TSS terjadi dikarena bahan organik mengalami degradasi pada saat proses hidrolisis. Saat proses hidrolisis terjadi, padatan tersuspensi tersebut menjadi berkurang dikarenakan telah berubah menjadi terlarut. Fitoplankton, zooplankton, lumpur, kotoran, tumbuhan, bakteri dan fungi merupakan zat-zat yang tersuspensi dalam air. Hasil lengkap seperti tersaji dalam Gambar 4.

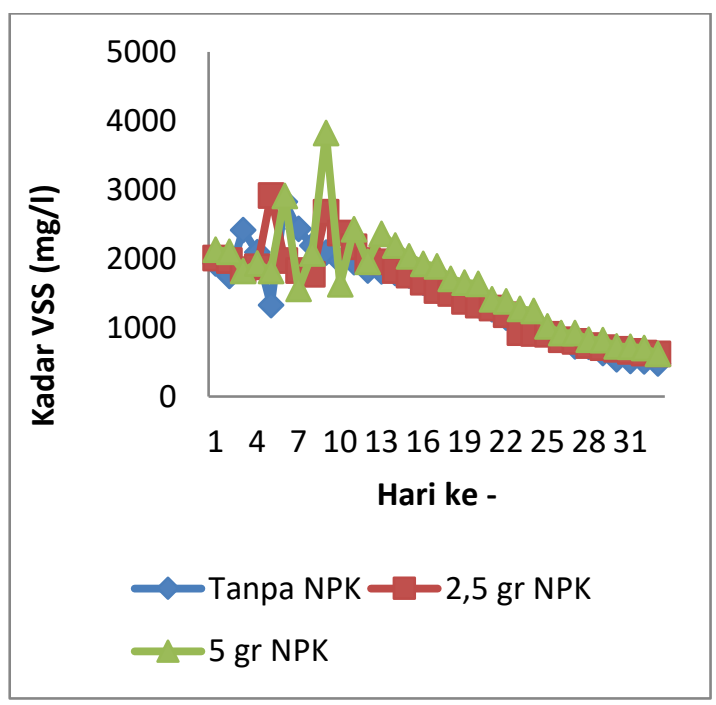

Gambar 4. Profil penurunan VSS (Volatile Suspended Solid) limbah cair kelapa sawit

Dari Gambar 4 dapat diketahui bahwa tingkat perubahan VSS sangat fluktuatif. Pada hari pertama analisa kadar VSS limbah cair kelapa sawit tanpa NPK yaitu $1.928 \mathrm{mg} / \mathrm{L}$ setelah 33 hari turun menjadi $476 \mathrm{mg} / \mathrm{L}$, penurunan 
kadar VSS sebesar $1.452 \mathrm{mg} / \mathrm{L}$. Untuk penambahan 2,5 g NPK, kadar TSS limbah cair kelapa sawit pada hari pertama yaitu 2.008,2 $\mathrm{mg} / \mathrm{L}$ turun menjadi $618,6 \mathrm{mg} / \mathrm{L}$ pada hari ke 33 , penurunan kadar VSS sebesar 1.389,6 $\mathrm{mg} / \mathrm{L}$. Pada penambahan $5 \mathrm{~g}$ NPK, kadar VSS limbah cair kelapa sawit dengan pada hari pertama yaitu $2008 \mathrm{mg} / \mathrm{L}$ turun menjadi $615 \mathrm{mg} / \mathrm{L}$ pada hari ke 33, penurunan kadar VSS sebesar 1.513 $\mathrm{mg} / \mathrm{L}$.

Pada Gambar 3 terlihat bahwa profil VSS untuk ketiga reaktor menunjukkan efisiensi pengurangan terbesar untuk ketiga parameter tersebut diperoleh pada penambahan $5 \mathrm{~g}$ NPK. Nilai VSS pada reaktor dengan penambahan NPK $5 \mathrm{~g}$ lebih tinggi dikarenakan pada penambahan ini terdapat banyak pasokan nutrisi yang berasal dari NPK yang menyebabkan mikroorganisme tersebut dapat tumbuh dan berkembang dengan baik. Sedangkan pada penambahan NPK 2,5 g hasilnya tidak jauh berbeda dengan penambahan NPK $5 \mathrm{~g}$ ini dikarenakan jumlah penambahan nutrisi untuk feses sapi lebih sedikit, tanpa penambahan NPK tetap terjadi penurunan akan tetapi masih tinggi, ketika diuji VSS senyawa anorganik yang ada pada reaktor tanpa NPK tersebut menguap dan mengakibatkan rendahnya nilai VSS.

\section{KESIMPULAN DAN SARAN}

Penurunan kadar COD, TSS, dan VSS terbesar dalam pendegradasian limbah cair kelapa sawit menggunakan anerobic baffled reactor yaitu pada penambahan NPK sebanyak 5 gram

\section{DAFTAR PUSTAKA}

Ahmad ,AL., Ismail, S. dan Bhatia, S., 2003, Water Recycling From Palm Oil Mill Effluent (POME) using membrane technology, Desalination, 157, p. 8795

Amatya, P L., 1996, Anaerobic Treatment of Tapioca Starch Industry Wastewater by Bench sacle Upflow Anaerobic Sludge Blanket (UASB) reactor. Master Thesis, Asian Institute of Technology, Bangkok, Thailand.

Anonim, 2018, Hasil Laboratorium PTPN VII Unit Bekrie, Lampung Tengah.

Appels, L., Baeyens, J., Degreve, J., dan Dewil, R. (2008). Principles AndPotential Of The Anaerobic Digestion Of Waste-Activated Sludge. Progress in Energy and Combustion Science. 34:755-781.

Behrendt, J., 2000, Modelling of Aerated Upflowed Fixed Bed Reactors for the Nitrification,

Bell J., 2002. Treatment of Dye Wastewaters in The Anaerobic Baffled Reactor and Characterisation of The Associated Microbial Populations. Ph.D. Thesis, School of Chem. Eng., Univ. of Natal, Durban

Colleran E, Finnegan S, Lens P. 1995. Anaerobic Treatment of SulphateContaining Watestreams. Antonie Van Leeuwenhoek, International J. General Molecular Microbiol; 67:29-46.

Dhamayanthie , I., 2000, Pengolahan Limbah Cair Industri Textile dengan Proses Anaerob, Thesis Master, Program Studi Teknik Kimia, Program Proses Sarjana ITB Bandung.

Davis M.L. dan Cornwell, D.A., 1991, Indroduction to Enviromental 
Engineering, $2^{\text {th }}$ ed., McGraw Hill, New York.

Eckenfelder, W.W., 1989, Industrial Water Pollution Control, $2^{\text {th }}$ ed., McGraw Hill Inc., New York.

Fauzi, Y., 2008. Teknik Pengomposan Tandan Kosong Kelapa Sawit. Jakarta

Herawati, D.A., dan Andang, A.W. (2010). Pengaruh Pretreatment Jerami Padi pada Produksi Biogas dari Jerami Padi dan Sampah Sayur Sawi Hijau Secara Batch. Jurnal Rekayasa Proses. 4(1): 25-29.

Kementerian Negara Lingkungan Hidup. 2004. Peraturan Menteri Negara Lingkungan Hidup Nomor 05 Tahun 2004 tentang Baku Mutu Air Limbah bagi Kawasan Industri. Jakarta: Kementerian Negara Lingkungan Hidup

Lettinga, G., Zehnder, A.J.B., Grotenhuis, J.T.C., and Hulshoff Pol, L.W., 1998, Granular Anaerobic Sludge, dalam Rittmann, B.E., and McCarty, P.L., 2001, Environmental Biotechnology : Principle and Applications, McGraw Hill International Ed., New York

Lettinga, G., van Velsen, A.F.M., Hobma, S.W., de Zeeuw, W. dam Klapwijk A., 1980, Use the uplflow sludge blanket (USB) reactor concept for biological wastewater treawtment especially for anaerobic treatment, Biotech, and Biong., Vol. 27, pp. 699-734

Loebis, B. dam P.L Tobing, 1989. Potensi Pemanfaatan Limbah Cair Industri Kelapa Sawit. Buletin Perkebunan 20(1). Hal 49-56.
Loebis, B. dam P.L Tobing, 1994. Penggunaan Betagen-Rispa Untuk Pengendalian Limbah Pabrik Kelapa Sawit, Berita PPKS, Vol. 2.

Manahan, S.E., 1994, Environmental Chemistry, $6^{\text {th }}$ ed. Lewis Publisher, USA.

McCart, P.L., 1964, Anerobic Wastewater Treatment Fundamentals, Part III, Toxic Materials and Their Control, dalam Rittmann, B.E., and McCarty, P.L., 2001, Environmental Biotechnology : Principles and Applications, McGraw Hill International Ed., New York.

McCarty, P.L., and Smith, D.P., 1991, Anerobic Wastewater Treatment, dalam MetCAlf \& Eddy, 2003, Watewater Engineering : Treatment, Disposal and Rause, $4^{\text {th }}$ ed., McGraw Hill Book Co., New York.

MetCalf \& Eddy, 2003, Wastewater Engineering : Treatment, Disposal and Reuse, $4^{\text {th }}$ ed, McGraw Hill Book Co., New York.

Naibaho, P.M., 1998, Teknologi Pengolahan Kelapa Sawit, Pusat Penelitian Kelapa Sawit, Medan.

Pambudi, N.A., 2008. Pemanfaatan Biogas sebagai Energi Alternatif. Jurusan Teknik Mesin dan Industri, FakultasTeknik :Universitas Gajah Mada.

Ridlo, R., 1996, Simulasi Model Frmentasi Metana Secara Anaerobik, Alami, Vol. 1 No. 2 
Rittmann, B.E.,and McCarty, P.L., 2001, Environmental Biotechnology : Principles and Applications, McGraw Hill International Ed, New York.

Said, E.Gumbira, 1996. Penanganan dan Pemanfaatan Limbah Kelapa Sawit. Cetakan Pertama. Bogor : Trubus Agriwidya.

Schmidt, J.E., and Ahring, K., 1996, Granular Sludge Formation in UASB Reactors, dalam Agustian, J., 2003. Immobilization of activated Sludge in A Column type Upflow Anaerobic Sludge Blanket Reactor, Majalah IPTEK, Vol. 14 No.14. hal. 185-192.

Spaan, H.A., 1983, An Approach to Wastewater Problem of The Palm Oil Industry in Indonesia, dalam Tobing, P.L., and Loebis, S., 1994, Penggunaan Betagen-Rispa Untuk Pengendalian Limbah Pabrik Kelapa Sawit, Berita PPKS, Vol.2

Speece, R.E., 1983, Anaerobic Biotechnology for Industrial Wastewater Treatment, dalam BPPT, 1997a, Teknologi Pengolahan Limbah Tahu-Tempe Dengan Proses Biofilter Anaerob dan Aerob,

Tembhurkar, A.R., dan Mhaisalkar, V.A. (2007). Studies on Hydrolysis and Asidogenesis of Kitchen Waste in Two Phase Anaerobic Digestion. Journal of PHE. 2007-08(2): 10-18.

van Lier, J.B., 1996, Limitation of Thermophilic Anaerobic Wastewater Treatment and Consequences for Process Design, dalam Metcalf \& Eddy, 2003, Wastewater Engineering :
Treatment, Disposal and Reuse, $4^{\text {th }}$ ed., McGraw Hill Book Co., New York.

WEF, 1998, Design of Wastewater Treatment Plants, dalam MetCalf \& Eddy, 2003, Wastewater Engineering : Treatment, Disposa; and Reuse, $4^{\text {th }} \mathrm{ed}$, McGraw Hill Book Co., New York.

Wilkie AC, Goto M, Bordeaux FM, Smith PH. 1986. Enhancement of Anaerobic Methanogenesis from Napiergrass by Addition of Micronutrient. Biomass; 11:135-146

Young, J.C., 1991, Factors Affecting the Design and Performance of Upflow Anaerobic Filters, dalam MetCald \& Eddy, 2003, Wastewater Engineering : Treatment, Disposal and Reuse, $4^{\text {th }}$ ed., McGraw Hill Book Co., New York

Zinder, S.H, and Koch, M., 1984, NonAcetilastic Methanogenesis from Acetate : Acetate Oxidation by a Thermophilic Syntropic Coculture, dalam MetCalf \& Eddy, 2003, Wastewater Engineering : Treatment, Disposal and Reuse, $4^{\text {th }}$ ed, McGraw Hill Book Co., New York 
